\title{
Gorgo: Sparta's Woman of Autonomy, Authority, and Agency
}

[Hdt. 3.148-3.149, 5.42, 5.46, 5.48-5.51, 5.70, 6.65-6.67, 6.137-6.140, and Hdt. 7.238-7.239]

\author{
By Oliver R. Baker
}

\begin{abstract}
Claims that Herodotus reveals himself as a proto-biographer, let alone as a protofeminist, are not yet widely accepted. To advance these claims, I have selected one remarkable woman from one side of the Greco-Persian Wars whose activities are recounted in his Histories. Critically it is to a near contemporary, Heraclitus, to whom

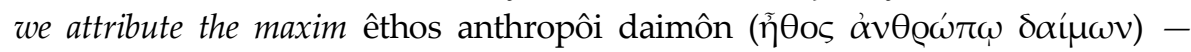
character is human destiny. It is the truth of this maxim-which implies effective human agency - that makes Herodotus' creation of historical narrative even possible. Herodotus is often read for his vignettes, which, without advancing the narrative, colorin the character of the individuals he depicts in his Histories. No matter, if these fall short of the cradle to grave accounts given by Plutarch, by hop-scotching through the nine books, we can assemble a partially continuous narrative, and thus through their exploits, gauge their character, permitting us to attribute both credit and moral responsibility. Arguably this implied causation demonstrates that Herodotus' writings include much that amounts to proto-biography and in several instances - one of which is given here-proto-feminism.
\end{abstract}

\section{One of So Very Few}

Herodotus names very few Hellenic women in his Histories, ${ }^{1}$ let alone assigning many of them significant roles during the Greco-Persian Wars, but his readers must readily note that in terms of political judgment he has nothing but praise for one royal Spartan woman-Gorgo (Гo@ $\left.\gamma \omega \omega^{\prime}\right)$ - who is born somewhat later than Atossa of Persia but about the same time as Artemisia of Halicarnassus and Gorgo is therefore her contemporary. ${ }^{2}$ Women are mentioned 375 times by Herodotus. ${ }^{3}$ But when including Hellenes, Barbaroi, Greek divinities, and other mythological figures, he actually names fewer than fifty women and very few of these are Hellenes. As is often the case, the biographical details that Herodotus gives of many individuals fall far short of fully developed cradle to grave

"Tutor-Marker and Graduate Student, Simon Fraser University, Canada.

1. All quotations from the Histories are from the Andrea Purvis translation presented in Robert Strassler, The Landmark Herodotus (New York, NY: Random House, 2007).

2. We do not know when Artemisia, the governor or queen of Halicarnassus, is born-but when first mentioned by Herodotus she is a widow and is serving as regent for her underage son Hdt.7.99.1-3. Nor does Herodotus mention when the late tyrant of Halicarnassus-her forever-unnamed husband-dies. Whether an able ruler or not, he has served his primary purpose-ensuring the succession. Her name is certainly theophoric.

3. Carolyn Dewald, “Women and Culture" Women's Studies 8, no. 1/2 (1981): 94, 125. 
assessments. But that is not to say that these gleanings defy either expansion in context or interpretation; or that in many cases that these oblique references and anecdotes cannot be pieced together to form a reasonably continuous narrative. Much more was very likely widely known about Gorgo at this time, even outside of Sparta, but perhaps for this reason alone these details are edited out by the author and dismissed as commonplaces of minimal contemporary audience interest-we can speculate, but we will never know. ${ }^{4}$

\section{An Only Child}

Gorgo is the only known legitimate child of Cleomenes I, the Agiad king of Sparta; and she becomes the wife of Leonidas I-the Spartan dyarch killed in battle at Thermopylae-and the mother of Pleistarchus, dyarch of Sparta from 479 to 458 . Since Gorgo's own son is still a minor upon his father's battlefield death in the late summer of 480 , initially his only surviving uncle Cleombrotus and then his first-cousin Pausanias serve as his regents. ${ }^{5}$ Whether as dowager queen-consort Gorgo assumes a significant role in the Spartan court, Herodotus does not say. Although the Ephors will change annually she will know of them and they of her, and she will be entirely familiar with many members of the Gerousa including, of course, the kings or the appointed regent. ${ }^{6}$

4. See the "Sayings of Spartan Women" where Plutarch includes six sayings, which he attributes to Gorgo, Frank Cole Babbitt, Moralia (Cambridge, MA: Harvard UP, 1931): 451469). These appear to be in character, and although he does not credit his sources for these, none of them come from Herodotus-this gives some credence to the notion that Herodotus makes his own selection from many now long-lost anecdotes about her.

5. Never great at chronology and indeed why let that spoil a good story-a fault largely attributable to his own and his sources' lack of a supranational calendar and dating system-Herodotus exaggerates Gorgo's youth in this anecdote from 499, perhaps to make her appear exceedingly precocious and her father rather doting. She is already married to her uncle on her father's death in 490/489 and since her son comes out of regency in 479, we can surmise that she married Leonidas a year or so after this bribery incident, putting her year of birth around 516 as was Artemisia's. Nevertheless, Gorgo is the daughter, wife, and mother of a Spartan king. The Persian queen, Atossa, is some thirty-five years older.

6. Sparta has a five-member Board of Ephors elected annually by the Assembly which comprises all male Spartan citizens; and, the Gerousa, a thirty-member Council of Elders - the two kings plus twenty-eight men aged over sixty but elected for life by the Assembly. This Assembly, known as the Ekklesia, would always be required to vote on matters of peace or war. Paul Cartledge, The Spartans (London, Pan Macmillan, 2002): 4546. 


\section{Heraclid Heritage}

The significance of Gorgo's possibly theophoric name is arguably an interesting anachronism which cannot be overlooked, whatever its meaning. At the very least it constitutes a challenge to established, late sixth-century, divine Greek myth for the child on the part of her royal parents. According to Hesiod's Theogony the Gorgons are female monsters of frightening appearance where even a lock of Medusa's hair can defeat an entire army. ${ }^{7}$ However, over time, the beauty/ugliness-desire/fear ambivalence fades and by the fifth century the Gorgons are portrayed as beautiful young women. ${ }^{8}$ In addition, Gorgo's name

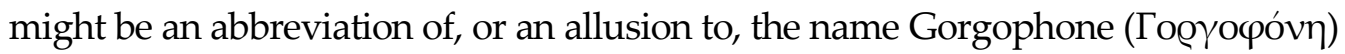
which translates as 'gorgon-slayer" a reference to Perseus' greatest deed-his beheading of the only mortal Gorgon-Medusa. ${ }^{9}$ Gorgophone is the daughter of Perseus and Andromeda. One of the sons of Oibalos, Gorgophone's first husband, is Tyndareus, stepfather of Helen of Troy and Pollux, and father of Clytemnestra, and Castor, and another son is Icarius, father of Penelope, Odysseus' spouse. One of their great-great-grandsons is Heracles. There is also the possibility that parallel to the obvious mythical allusions, Cleomenes is literally having fun-no parent would name their child after a terrifying monster. ${ }^{10}$

Such an abundance of Homeric and mythical allusions cannot be happenstance. Cleomenes is blessed with only one child and he brings her up much as he might the son and heir he did not have, but with similar great expectations. ${ }^{11}$ As the Agiad king's patrouchoi ( $\left.\pi \alpha \tau \varrho \circ \tilde{\chi} \chi \mathrm{ol}\right)$ she is at once the most

7. Richard Caldwell, Hesiod's Theogony (Newburyport MA: Focus, 1987): 270-279. These myths are extended by later writers, including Apollodorus and Pausanias.

8. See the Gorgo/Medusa entry by J. N. Bremmer in the Oxford Classical Dictionary, Simon Hornblower et al. (Oxford: Oxford UP, 2012). Herodotus gets his chronology in 490 quite wrong when he writes, ". . since Kleomenes did not rule for long but died without having sired a son. He left behind only a daughter; whose name was Gorgo" (Hdt. 5.48). Whether he dies or is assassinated before or after the battle of Marathon is not known.

9. This mystery is raised by at least one Spartan scholar; but not quite flummoxed he nevertheless hesitatingly shies from the notion that her name is the Spartan equivalent of the 1969 "A Boy Named Sue" challenge by J. R. (John) Cash/Shel Silverstein, Cartledge Spartans (2002): 104-105.

10. Today, parents naming their daughter Georgina risk the nickname George sticking. The English boy's name ultimately derives from the Ancient Greek Geōrgios

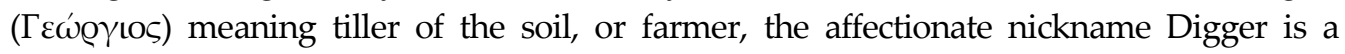
possibility.

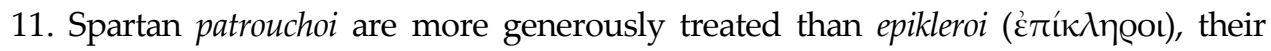
counterparts elsewhere in mainland Greece. In Greek drama, Antigone, Oedipus' eldest daughter in Sophocles' tragedy the Antigone, becomes an epikleros when her two brothers Eteocles and Polynices are killed and the new Theban ruler, her uncle Creon, becomes responsible for her marriage as well as that of her younger sister Ismene. 
powerful and easily the most desirable of contemporary Spartan heiresses. ${ }^{12}$ Arguably the path to the throne offered by Gorgo and Helen of Sparta, to respectively Leonidas and Menelaus, are variants of male-preference primogeniture. ${ }^{13}$ Given their age differences, it is possible that Leonidas either puts aside an earlier spouse, or more likely simply remains unmarried until his niece, Gorgo, has reached her late teens.

\section{The Son He Never Had}

One of Herodotus' more delightful anecdotes and perhaps the one which constitutes her one character-defining moment concerns Cleomenes' early fifthcentury meetings with the Ionian tyrant Aristagoras, at the last of which Gorgo is in attendance. ${ }^{14}$ Aristagoras, the tyrant of Miletus, seeks Spartan assistance in a proposed Ionian quest for independence, but Cleomenes is unconvinced and delays his decision. ${ }^{15}$ It is when they next meet that Cleomenes learns how far inland the Persian capital, Susa, lies. ${ }^{16}$ At this point Cleomenes says: ${ }^{17}$

12. Herodotus points out that by the Spartan interpretation of male-preference primogeniture rules, because Cleomenes has no male heir, if Dorieus, the eldest of Cleomenes' younger half-brothers, had not been killed in 510 during a forlorn attempt to found an independent Spartan colony in Sicily he would have succeeded to the throne on Cleomenes' death (Hdt. 5.48 and Hdt. 5.42-5.46.1). Interestingly, neither of Dorieus' younger brothers, Leonidas or Cleombrotus, joins him in these colonial misadventures.

13. Tyndareus is king of Sparta, but his consort, Leda, gives simultaneous birth to two sets of twins-Clytemnestra and Castor fathered by him and to Helen and Pollux fathered by Zeus. Myths vary, but in most Castor and Pollux predecease Helen, and after Menelaus marries Helen Tyndareus and Leda abdicate the Spartan throne in their favor. Therefore, one reason why Menelaus is so anxious to recover Helen is because her presence as his spouse legitimizes his rule in Sparta.

14. Hdt. 5.49-5.50. This meeting in Sparta takes place in 499, well before the foolish if not abortive Ionian raid on Sardis in 498. This raid, in which the Ionians are supported by contingents from Athens and Eretria, is one of the causes of the first Greco-Persian war.

15. Hdt. 5.49.9.

16. Hdt. 5.50.1-2 and Hdt. 5.49.5-7. At one stage Aristagoras produces a map engraved on a tablet; but whether it really shows to scale that Ephesus, a likely port for any invasion force, is around 300 nautical miles away from the Peloponnesus, that Sardis, a provincial capital, is over 100 kilometers from Ephesus, and that Susa, the Persian capital, another 2,700 kilometers from Sardis, Herodotus does not say.

17. The Andrea Purvis translation of the Histories, reproduces all of Herodotus' tense shifts. So direct speech (see Hdt. 5.50.3 above) is always present tense, but his narrative (see Hdt. 5.51.1-3 above) is past narrative. Since my own text is present narrative, some tense confusion cannot be avoided. 
"My guest friend of Miletus, you must depart from Sparta before sunset. Your request will never be accepted by the Lacedaemonians if you intend to lead them on a three-month journey away from the sea" (Hdt. 5.50.3).

Note that he says, "accepted by the Lacedaemonians" a clear indication that an affirmative vote from the Assembly is mandatory. Herodotus does not say where this meeting takes place, but he does say that despite the formal public banishment decree Aristagoras follows Cleomenes home. ${ }^{18}$ The inference is that their first meeting is in some public place, perhaps with several ephors or members of the Gerousa in attendance. He also uses the word home rather than palace; the inference is that the Spartan dyarchs do not indulge in the use of splendid personal accommodation during their reign.

He first asked Cleomenes to send away the child there, for his daughter whose name was Gorgo was standing beside the king. He happened to have only this one child, who at that time was about eight or nine years old. Cleomenes ordered Aristagoras to speak out and say what he wanted and not to hold back because of the presence of the child. [2] So Aristagoras began by promising him ten talents if he would fulfill his request. Cleomenes refused, and Aristagoras increased the sum step by step, until he has raised the offer to fifty talents. At this point the child blurted out, "Father, your guest-friend is going to corrupt you unless you leave and stay away from him." [3] Cleomenes was pleased with his child's advice, and he went into another room. Aristagoras departed and then left Sparta completely, losing the opportunity to explain the journey inland to the king any further (Hdt. 5.51.1-3).

If Cleomenes' only child had been male, the boy might well have been sent off to the Agoge when aged seven and would rarely see either his mother or his father; as things turn out Cleomenes gets the best of both worlds and he is able to raise and perhaps indulge his only child at home throughout her childhood and adolescence.

\section{Spartan Education and Ethics}

Why Herodotus should include this anecdote leads to more questions than answers. We know very little about the inner workings of the Spartan court, but evidently diplomatic visitors can seek private audiences with one of the kings or perhaps with one or more of the ephors. A royal child's silent attendance might

18. Hdt. 5.51.1. 
be a compulsory part of their upbringing. ${ }^{19}$ Neither illiterate nor innumerate, these young Spartan women acquire not only the same grounding, if not much better, in the three R's as their male siblings; but in addition, the wonderful potentially off-road freedom from close surveillance afforded by the fourth $\mathrm{R}-$ riding. ${ }^{20}$ The one-hour horse-ride horizon is vast compared to that accessible on foot. And it matters little whether this riding was astride or aside-it would be another millennium before the saddle is invented.

In contrast, if ever allowed outside the home, Athenian women are driven by others, trusted male slaves, in covered wagons. And famously, even a Phaeacian princess has to inveigle her doting father for permission to drive the wagon loaded with laundry and her maid-servants; although her confidence and skill with mule team suggests that she was no novice and this was not the first time he had acquiesced in granting such freedom. ${ }^{21}$ Although the lifestyle of the Spartan people is already synonymous with simplicity and communal austerity, we are obliged to ask whether individuals, particularly those in positions of influence, were invariably immune to bribery? ${ }^{22}$ Evidently Aristagoras believes that the Agiad Spartan king can be bribed; but whether Aristagoras, the tyrant of Miletus, fully understands the intricacies of Sparta's almost unique dyarchy-two kings, neither being an absolute ruler, who must work in conjunction with the Board of Ephors, the Council of Elders, and ultimately the Assembly-Herodotus does not say.

But Aristagoras is hardly the first ruler to harbor misconceptions about how most effectively to influence Spartan leadership, and furthermore ultimately to be disappointed. Herodotus tosses in the salacious tale that some ten years earlier Cleomenes is known to have been extraordinarily friendly with the wife of the Athenian aristocrat Isagoras. ${ }^{23}$ However, much Cleomenes may well have enjoyed her bedroom favors and she his; given the complex decision-making process in

19. For general comments on the education of young female children in Sparta, see Sarah Pomeroy, Spartan Women (Oxford: Oxford UP, 2002): 3-32.

20. We hardly need Fay Weldon-a feminist author before the word was even coined - to point out that possession of these four " $\mathrm{R}^{\prime} \mathrm{s}$ " ultimately leads to acquisition of the three "A's" - autonomy, authority, and agency - and the cost-accountability-trivial and not unreasonable, the first three " $\mathrm{A}$ ' $\mathrm{s}$ " engendering the fourth.

21. Od. 6.39-44, 6.61-65, and 6.80-94, see Robert Fagles, Homer: The Odyssey (New York, NY: Viking Penguin, 1990).

22. The word spartan enters the English language as a noun for austerity and indifference to luxury during the seventeenth century. Notwithstanding this famed austerity, Herodotus and Thucydides are littered with instances of Spartan leaders both offering and accepting bribes.

23. Hdt. 5.70.1. Of course, she is an Athenian aristocrat and therefore remains unnamed, but likely not at all unknown to the more influential contemporary Athenian politicians, some of whom may have been offered and even accepted similar carnal inducements by Isagoras. 
Sparta, Isagoras' pandering his spouse likely results in only their mutual delight without achieving the desired significant influence on any diplomatic outcome. ${ }^{24}$

Evidently, in this instance, Herodotus is letting an otherwise naïve female teenager make the obvious point that no matter where one is positioned in politics and diplomacy, almost everyone ultimately has a price. ${ }^{25}$ This is not to say that once Cleomenes accepts Aristagoras' clumsy silver bullion bribe he can or would even consider ever following through. But more importantly to Gorgo is the notion that, by even listening, her father risks dragging the Agiad kingship and Sparta in general into disrepute. This is a broad jab to his contemporary readers that other Greek city-states-piously proffering the usual and expected denials-are also demonstrably susceptible to political and judicial corruption. ${ }^{26}$

Moreover, Herodotus is setting the stage so that after her Agiad dynastyrepairing marriage Gorgo can be regarded as the equal in stature of such legendary Homeric consorts as at least Andromache in the Iliad, or in much more flattering terms to Penelope in the Odyssey. ${ }^{27}$ However, until Gorgo marries, the best model or fit in Homeric terms for a vivacious and intelligent young woman of royal birth, welcome and active in her parent's court, is the beautiful Phaeacian princess, Nausicaa. ${ }^{28}$ She has that rare ability to immediately discern nobility, virtue, and character despite all outward appearances. ${ }^{29}$ Conversely Gorgo instantly discerns that Aristagoras lacks all of these attributes and-like many self-serving politicians - that he has absolutely nothing to say worth listening to.

24. As Heywood surmises, it would be "an yll wynde, that blowth no man to good, men saie." John Heywood, A Dialogue Conteining ... (London, 1546): Part ii, Chap ix).

25.Irrespective of how her sense of morality and perhaps ethics are instilled they are a part of her royal upbringing, Gorgo's suggestion that Cleomenes leaves the room shows she is gentler, kinder, and more diplomatic than her father. Earlier in his reign, when Maiandrios of Samos attempts to bribe him, the young king immediately informs the Ephors and recommends that Maiandrios be banished from the Peloponnese lest he succeed in corrupting other leaders (Hdt. 3.148.1-3.149.1).

26. Gorgo's father is outraged to learn that the Athenians have corrupted the oracle at Delphi to garner Spartan support (Hdt. 6.123.2), but less than two decades later Cleomenes will bribe the Pythia-Periallos - to aid in his deposing of Demaratos (Hdt. 6.66.1-3). Note that in this case-perhaps because the Pythia's behavior is disreputable-her name is given.

27. See books 6 to 8 of the Odyssey, set before Odysseus begins his storytelling after washing up on the shores of Scheria (probably Corfu). Nausicaa is the only daughter of King Alcinous and Queen Arete of the island kingdom of the Phaeacians. Fagles trans., the Odyssey.

28. As usual, Herodotus tells us nothing about Gorgo's physical appearance; but we can argue from his silence that it was quite unremarkable, not rivalling that of Helen of Sparta or he would have said as much-clear eyes not too close together: neither drop-dead gorgeous nor excessively long of limb or nose.

29. Od. 6. 148-158. Fagles trans., the Odyssey. 


\section{A Dutiful Princess}

A year or so after this incident Gorgo marries her uncle Leonidas, her father's half-brother by a different mother. Endogamy - then as now a favored pastime of many royal houses and the landed aristocracy -is a commonly accepted practice by the Greeks, including Athenians and Spartans. ${ }^{30}$ In Gorgo's case-despite what in modern terms we might regard as distressing consanguinity-her marriage tidies up a major loose end in the Agiad line of succession. When his spouse appears to be barren, Gorgo's grandfather, Anaxandridas, is reluctantly persuaded by his Council of Ephors to enter into a bigamous marriage-a union which promptly produces the required son Cleomenes, Gorgo's father. Most surprisingly and shortly thereafter Anaxandridas' first wife, unnamed, of course, quickly gives birth to three sons: Dorieus, Leonidas, and Cleombrotus thereby clouding the Agiad succession. ${ }^{31}$ Gorgo's father may have spent a lifetime deprived of the secure knowledge of his Agiad legitimacy - the ephors who forced the issue are long gone and many of those elected to the Gerousia will have passed away. One way or another, this marriage removes any cloud.

Herodotus tells one last anecdote concerning Gorgo in the year 485.32 And we should be mindful that these are flattering anecdotes that he cannot possibly

30. Leonidas (his name a loose reference to the lion-slaying Heracles) was born around the year 540 and would be expected to marry when in his late twenties. As Cartledge points out, unless he was widowed or set aside an earlier bride, he would be in his mid-forties when he marries the teen-aged Gorgo. Cartledge, Spartans, 242-243.

31. Although entirely of their own making the ephors' dilemma is simple-is the true heir apparent the absolute first-born, albeit by the second, possibly bigamous union-or is he the somewhat younger first-born male child by Anaxandridas' first and unquestionably legitimate spouse? They can stall for a few years to see which children survive infancy, but not forever.

32. Classicists will recall that within Plutarch's Moralia he devotes a chapter to "Sayings of Spartan Women"-Lacaenarum Apophthegmata-there is no such chapter for Athenian women, nor for any other group of women Babbitt, 451-469. However, Plutarch has a not entirely relevant chapter also among his Moralia entitled "Bravery of Women" - Mulierum Virtutes, Babbitt 471-581. Athenian men insisted on protecting their wives, sisters, and daughters from the public sphere, consequently like little Victorian children they were to be rarely seen and seldom heard. In fact, if an Athenian woman's name is given, more likely

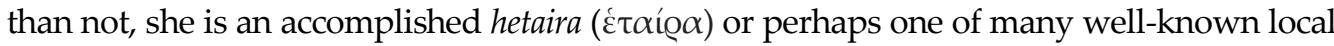
pornai ( $\pi$ ó $v \alpha \mathrm{l}$ ) rather than a noblewoman-Aspasia of Miletus-Pericles' concubine comes to mind. 
tell about contemporary Athenian women. ${ }^{33}$ During this period Athenian women whether aristocratic or ordinary citizens are confined to the domestic sphere and generally cannot appear in public-unless it is to attend an all-female religious festival. ${ }^{34}$ But whether Herodotus' audiences ever notice this remarkable inclusion in his Histories of an independent and gifted woman, who was neither an Amazon nor a courtesan, contemporary Greek commentators do not say.

When Demaratos son of Ariston was in exile among the Medes, I do not believe-and here reason is my ally-that he had goodwill toward the Lacedaemonians, though one may conjecture whether he acted out of benevolence or out of spiteful satisfaction. For when Xerxes resolved to lead an expedition against Hellas, Demaratos was in Susa, and upon learning Xerxes' plans, immediately wanted to communicate this information to the Lacedaemonians. [3] There was a risk that he would be caught, so there was no other way he could inform them except by the following scheme. Taking a double writing tablet, he scraped off the wax and inscribed the plan of the King onto the wood of the tablet. After doing this he melted some wax back over what he had written, so that the tablet would be apparently blank and thus cause no trouble from the guards as it was conveyed to its destination. [4] When it arrived at Lacedaemon, the Lacedaemonians could not understand what it meant until, according to what I have heard, Gorgo the daughter of Cleomenes and wife of Leonidas deduced the answer herself. She ordered them to scrape off the wax, and said that they would then discover a message written on the wood (Hdt. 7.239.2-4).

33. This sounds much like an Archaic Athenian variant of "Kinder, Küche, Kirche" (aber keine Komödie). Without giving any clues toward a date, we can only assume that it was late in the sixth century, Herodotus describes how the Pelasgians, who were at one time justly expelled from Attica by the Athenians, some of whom settled on Lemnos in the northern Aegean and from there plotted their revenge. Some years after the expulsion they raid the temple at Brauron during the annual Festival to Artemis abducting many young Athenian women to be distributed among themselves as concubines, or forced into more common use. As the religious ritual was performed entirely by teenaged women, very few men, other than the covered wagon drivers, would be in attendance making the raid particularly cowardly (Hdt. 6.137.3-6.140.2).

34. In a comparison between Spartan and Athenian women Paul Cartledge comments that young Spartan women "were married at eighteen-a substantially later age than their Athenian counterparts" Spartans, 24. 


\section{A Queen's Place among Courtiers}

To claim Gorgo as the first female cryptanalyst overstates the case as she is not deciphering Demaratos' message, just revealing it. ${ }^{35}$ But in closing book 7 of his Histories Herodotus goes out of his way to make the case that where a roomful of men-supposedly Sparta's brightest and best-are utterly flummoxed, she is not. ${ }^{36}$ There is no evidence that Gorgo shares her father's enmity with Demaratos. Indeed, this incident suggests that she knew him sufficiently well to be confident that he would not risk his life with any secret communication without good reason. Again, why Herodotus should include this anecdote raises interesting questions far beyond the ethnic (Athenian) slur that all Spartan males were Neanderthal Heraclids bred for brawn and not brain. He is sorting through and selecting from any number of near contemporary but unwritten stories in current circulation from his sources in the Peloponnese and Attica. ${ }^{37}$ Most stories improve with the telling and Herodotus is certainly free to creatively re-work his source material both to his liking and to that of his audiences.

Arguably we can make the case that Herodotus is also a proto-feminist, almost two and a half millennia before the word is ever coined. Near the end of her article Lynette Mitchell writes, "It remains to ask whether it is significant that many of these women come from cities which might, from an Athenocentric point of view, be considered to lie on the edges of the Greek world." 38 Athenians may piously take their cue from Homer, and Hector in particular, who believes that women should solely "tend to . . . the distaff and the loom." 39 The center is often taken as the pinnacle of achievement, but it can equally be the slough of despair. No matter, we can make the claim that Gorgo, just to name one

35. Until deposed by Cleomenes in 491, in what can only be described as the dirtiest of deeds, including corruption of the oracle at Delphi, Demaratos was the Eurypontid king of Sparta (Hdt. 6.65.1-6.67.1). Banished from the kingdom, he eventually ends up an advisor at Xerxes' court. He may well have wished every ill of Cleomenes while harboring no illwill against the Spartan people.

36. See Lynette Mitchell "The Women of Ruling Families" Classical Quarterly 62, no. 1 (2012): 10. Arguably Gorgo is a very different heroine than Andromache, who is hardly praised by Hector for her listing of her personal losses during the course of the war and lamenting his role (Il. 6.480-520). But unlike Hector's spouse, Gorgo-who is more like Penelope-in a point raised in her article about the role of women in ruling families - is not telling her husband's courtiers how to conduct the war.

37. If, as might be inferred from a disparaging comment by Plutarch, Herodotus gave public performances of near-completed portions of his work, we could argue that the perceived bias or spin on any particular story is a palimpsest of the last audience to whom it was successfully presented, see Babbitt (Plu., Mor. 864D).

38. See Mitchell, “Ruling Families" 20.

39. Il. 6.585-586. To point out the obvious: Hector is killed in battle and his body mutilated, the infant Astyanax has his brains splattered over the walls of Troy, and Andromache is a live trophy to be taken away into involuntary concubinage by the victors. 
remarkable woman, earns her own place in Greek history on her own merits and not just upon those of the Spartan ruler to whom she is married or on those of her father. There is an unresolved paradox here-five of the Olympians are goddesses, of whom three are virgins, and are depicted in divine myth in their own ways as just as powerful as the Olympian gods. ${ }^{40}$ This leaves unexplained why the status of mortal women is generally so low.

\section{Gloomy Prophesies}

Long before leaving the Peloponnese for Attica and the Hot Gates of Thermopylae to meet the Persian invader, the Spartans consult Apollo's oracle at Delphi and for once the Pythia's prophecy is particularly gloomy but unequivocal. Her prophecy is a simple either-or-either their city [Sparta] would be sacked by the Persians or that their king would die. ${ }^{41}$ Herodotus does not recount Gorgo's reaction, but Plutarch does. She must know about the oracle and Plutarch suggests that she discusses what ifs with Leonidas. ${ }^{42}$ Nor does Herodotus discuss what the Spartan authorities thought of this either, but offers the suggestion that Leonidas immediately perceives the Achilles-like parallel-kleos or everlasting renown-partially explaining why he assumes overall command but eventually sends much of his force away to fight another day.

Herodotus' audiences will not miss the point that Gorgo is widowed when her husband accepts, if not actively seeks, the most gloriously Homeric of all battlefield deaths - fighting to almost the last man when his three hundred Spartan hoplites and disputed but likely similar numbers of loyal Thebans and Thespians are grossly outnumbered by Xerxes' army of tens of thousands. ${ }^{43}$ Her husband's battlefield death becomes even more Homeric when his remaining Spartan hoplites are killed when unsuccessfully trying to protect his corpse from Persian mutilation. Homer's battlefield heroes have a similar aspiration for what might be termed surrogate immortality stemming from eternal fame. ${ }^{44}$ Herodotus' contemporary audiences-steeped in Homer-may even compare and contrast

40. There are twelve (or perhaps thirteen) Olympian gods. Hestia (certainly sober and a virgin) is often displaced in the listings by Dionysus (most determinedly neither).

41. Hdt. 7.220.2-4.

42. See Babbitt 455-456, possibly an apocryphal tale, Gorgo encourages Leonidas to show himself worthy and asks him what she should do, and he replies, "Marry a good man, and bear good children" (Plu. Mor. 240.6E).

43. Patroclus is killed in battle by Hector (Il. 16.951-971), but much of the action of book 17 of the Iliad covers the subsequent fight over his armor and his corpse. On Xerxes' orders King Leonidas' corpse is mutilated and his severed head is mounted on an infantryman's spear-an unusual and ignominious treatment by the Persians of a brave warrior and monarch (Hdt. 7.238.1-2).

44. See Michael Clarke, "Spartan Atē at Thermopylae" Sparta: Beyond the Mirage (London: Duckworth), 65. 
her behavior with Hector's spouse-who berates his role and bewails his responsibilities-except that Gorgo is no weeping Andromache ${ }^{45}$-and with Odysseus' spouse-who accepts that such was her lot-indeed to win her Odysseus had devised and taken the Oath of Tyndareus himself and his duty was clear. ${ }^{46}$ Whether Gorgo ever questions her husband's motives is a matter Herodotus leaves largely unexplored - it is fair to ask whether in a Kantian sense Leonidas does all the right things at Thermopylae for all the wrong reasons. For some valor is necessarily selfless; although bravery may not be fearless, nor is it careless or suicidal. Herodotus actually comments on the two Spartan survivors of Thermopylae..$^{47}$

There is no evidence that Gorgo ever re-marries, indeed doing so might confound her son's succession; but equally - widowed to a Spartan hero-she has no interest in a potentially second-rate, second spouse. Herodotus has penned the outline of an enduring love story. ${ }^{48}$ But all this grief is in Gorgo's future - the two anecdotes from Herodotus above place her defining moments in the same context as the Phaeacian princess Nausicaa. Herodotus grants her the essential three A's - autonomy, authority, and agency, she becomes much more than just a royal incubator of the next Agiad dyarch; Fay Weldon would be proud.

\section{Feminism before there was a Word for it}

In the late Archaic and early Classical periods, we are so accustomed to learning of women in terms of the male figures with whom they are most closely

45. Il. 22.550-570 and Il. 24.893-912, see Fagles' translation.

46. Herodotus' audiences, many of whom know their Homer backward, will be familiar with Odysseus' views on companionate marriage, in particular where he wishes that with her future husband Nausicaa will find "two minds, [and] two hearts that work as one" (Od. 6.201-202).

47. Of the three hundred Spartans three were sent away from Thermopylae as messengers: Pantites, Eurytos, and Aristodemos. Pantites does not return to participate in the battle and hangs himself in disgrace, whereas Eurytos although blinded with an eye disease returns to fight and die in battle. Aristodemos, suffering from similar blindness, elects not return to Thermopylae and survives to live in ignominious disgrace. One year later he is killed during the battle of Plataea, but is denied any measure of kleos by his comrades because they believe that he wanted to die and deliberately makes a grandstand spectacle of his battlefield death. Hdt 7.229-7.231 and Hdt. 9.71.2-4.

48. Here we might recognize two aspects of Aphrodite's nature-“Aphrodite Urania, born of Uranus without a mother, represented intellectual, non-physical love. Aphrodite Pandemos, said to have been created by the union of Olympian Zeus and the sky goddess Dione, was the patroness of prostitutes and represented common or vulgar love" Pomeroy, Goddesses, Whores, 7. Accordingly, we might represent the dichotomy between the two sorts of love as that indicated by Nausicaa/Gorgo and Helen/Phryne. 
associated, where often even their names remain unrecorded, that we forget that mythology is loaded with exceptions. ${ }^{49}$ Paris, one of Queen Hecuba's nineteen children and an easily corruptible beauty pageant adjudicator to boot, would remain almost as completely unknown as the majority of Priam's other fifty sons, including his hapless younger brother Troilus, except for the status and fame of the woman he abducted. This identity paradox extends to the king of Locris, the Lesser Ajax son of Oileus, whose principal claim to Homeric fame is his mindless desecration of Athena's temple with the rape of Priam's daughter Cassandra, where the virgin priestess sought refuge during the sack of Troy-both so-called warriors appear to rely on the moral compass suspended below the belt rather than one above the shoulders for their moral guidance.

Herodotus goes out of his way to sketch-in some of the laudable accomplishments of a number of women-including Gorgo. Of course, they are someone's daughter, and admittedly it is their elite station in life that makes these deeds even possible. But once granted the autonomy, authority, and agency trident in hand-Herodotus shows that Gorgo waits on no man, neither her father nor her husband, let alone any of the ephors. Of course, Herodotus also describes the less laudable deeds of several other similarly trident-armed women-notably Nyssia and Amestris. ${ }^{50}$ One of Lewis Carroll's Queen of Hearts favorite commands, "Off with her head!" comes to mind. ${ }^{51}$ But what Herodotus' contrast really shows is that the trident can be used for good or ill and that possession of great power is not enough - the holder has to know how and when

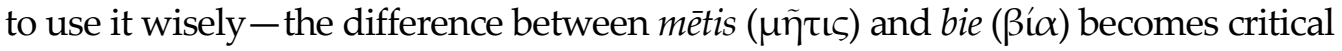
when resort to a Herculean display of strength is not an option.

\section{Acknowledgments}

The author gratefully acknowledges the autonomy, authority, and agency of Dr. Dionysia Eirini Kotsovili of the Stavros Niarchos Foundation Centre for

49. It can hardly go unnoticed that Zeus' first spouse is the Oceanid, Metis, a daughter of the two Titans Oceanus and Tethys. She is the goddess of wisdom, prudence, and deep thought whom, when tricked momentarily into turning into a fly, Zeus will swallow. This swallowing is partly to foil the prophesy that the son Zeus has by her will be more powerful than he is and partly to ensure that Metis can continue to give him wise counsel from within-ruminating perhaps? The Greek word metis ( $\mu \tilde{\eta} \tau \iota \varsigma)$-meaning cunning or crafty like a fox, or Odysseus-is not pejorative and often contrasted with bie ( $\beta$ í $\alpha$ ) brute force.

50. Nyssia is the spouse of the early seventh-century Lydian king Candaules, and Amestris is the principal wife of the fifth-century Persian king of kings, Xerxes.

51. See Lewis Carroll's 1865 Alice's Adventures in Wonderland. Throughout the fantasy, the Queen's remedy to any problem is to demand, "Off with his/her head!" or "Off with their heads!" 
Hellenic Studies at Simon Fraser University-not to mention her patient guidance-during preparation of this article.

\section{Bibliography}

Babbitt, Frank Cole (Trans. 1931.) Plutarch Moralia with an English translation, volume 3. "Sayings of Spartan Women" and "Bravery of Women." Loeb Classical Library Series No. 245. Cambridge, MA: Harvard University Press, reprinted to 2004.

Caldwell, Richard S. (trans.) Hesiod's Theogony. Newburyport, MA: Focus Classical Library, 1987.

Cartledge, Paul A. The Spartans: An Epic History. London, Basingstoke, and Oxford: Channel 4 Books, Pan Macmillan, 2002.

Clarke, Michael. "Spartan Atē at Thermopylae? Semantics and Ideology at Herodotus, Histories 7.223.4." In Sparta: Beyond the Mirage, edited by Anton Powell and Stephen Hodkinson, 63-84. London: The Classical Press of Wales and Gerald Duckworth \& Co., 2002.

Dewald, Carolyn. “Women and Culture in Herodotus' Histories." Women's Studies 8, no. 1/2 (1981): 93-127.

Fagles, Robert (Trans.) Homer: The Iliad. New York, NY: Viking Penguin, 1990. . Homer: The Odyssey. New York, NY: Viking Penguin, 1996.

Heywood, John. A Dialogue Conteinyng the Nombre in Effect of All the Prouverbes in the English tongue ... . London, 1546. EEBO. Bibliographic number STC (2nd ed.) / 13291.

Mitchell, Lynette G. "The Women of Ruling Families in Archaic and Classical Greece." Classical Quarterly 62, no. 1 (January 2012): 1-21.

Oxford Classical Dictionary. Fourth Edition. Simon Hornblower, Antony Spawforth, and Esther Edinow (Eds.) Oxford: Oxford University Press, 2012.

Strassler, Robert B. (Ed.) The Landmark Herodotus: The Histories. Translated by Andrea L. Purvis. New York, NY: Random House, 2007. 